\title{
GOLD EMBROIDERY AND FABRICS IN EUROPE: XI - XIV CENTURIES
}

\author{
MÁRTA JÁRO \\ National Centre of Museums, \\ H-1087 Budapest \\ Hungary
}

\begin{abstract}
Sophisticated scientific methods have opened up new dimensions in research into the metal threads decorating ancient textiles. At the same time, some of the results of the investigations have given rise to new questions to be answered. A review is given of the results and problems of this new field of research.
\end{abstract}

$\mathrm{T}$ he decoration of textiles with gold can be traced back thousands of years. The first written record of it is probably the quotation from the Bible (right) which describes the making of Aaron's vestment for service (ephod) about the 12-13th centuries $\mathrm{BC}$. The value and the glitter of gold have always attracted man. Besides wearing gold jewels, he has woven gold into textiles; he has used gold for embroidering his clothes; he has decorated his church and secular textiles with the preclous metal (Figs. 1, 2 and 3).
"And he made the ephod of gold, blue and purple, and scarlet, and fine twined linen. And they did beat the gold into thin plates, and cut it into wires,

to work it in the blue,

and in the purple, and in the scarlet, and in the fine linen, with cunning work."

Old Testament, Exodus, 39: 2-3
The gold threads that were used in embroidery and weaving were made in a variety of ways.

Generally speaking, they consisted of metal strips that were used either directly or, more often, in the production of composite threads, in which the metal strip was wound around a fibrous core of silk, linen, cotton or other yarns) (Fig. 4). Wire was also used directly or for winding around such cores (Fig. 5). Pure gold, gold alloyed with silver, gilded or gilt-silvered copper and gold-like copper 


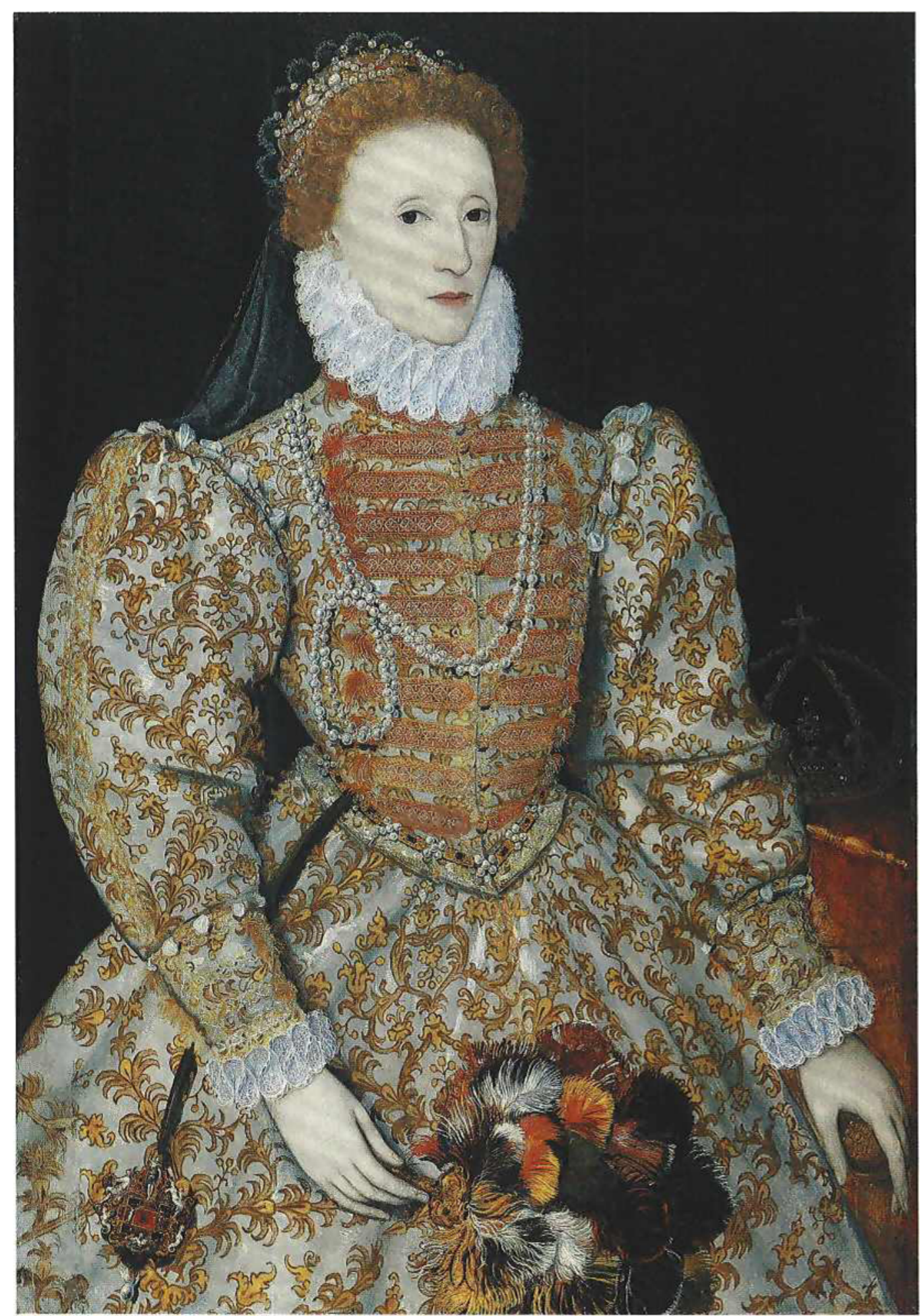

Fig. 1

Queen Elizabeth I, wearing a dress richly embroidered with gold thread (oil painting by an unknown artist, 16th century,

National Portrait Gallery, London) 


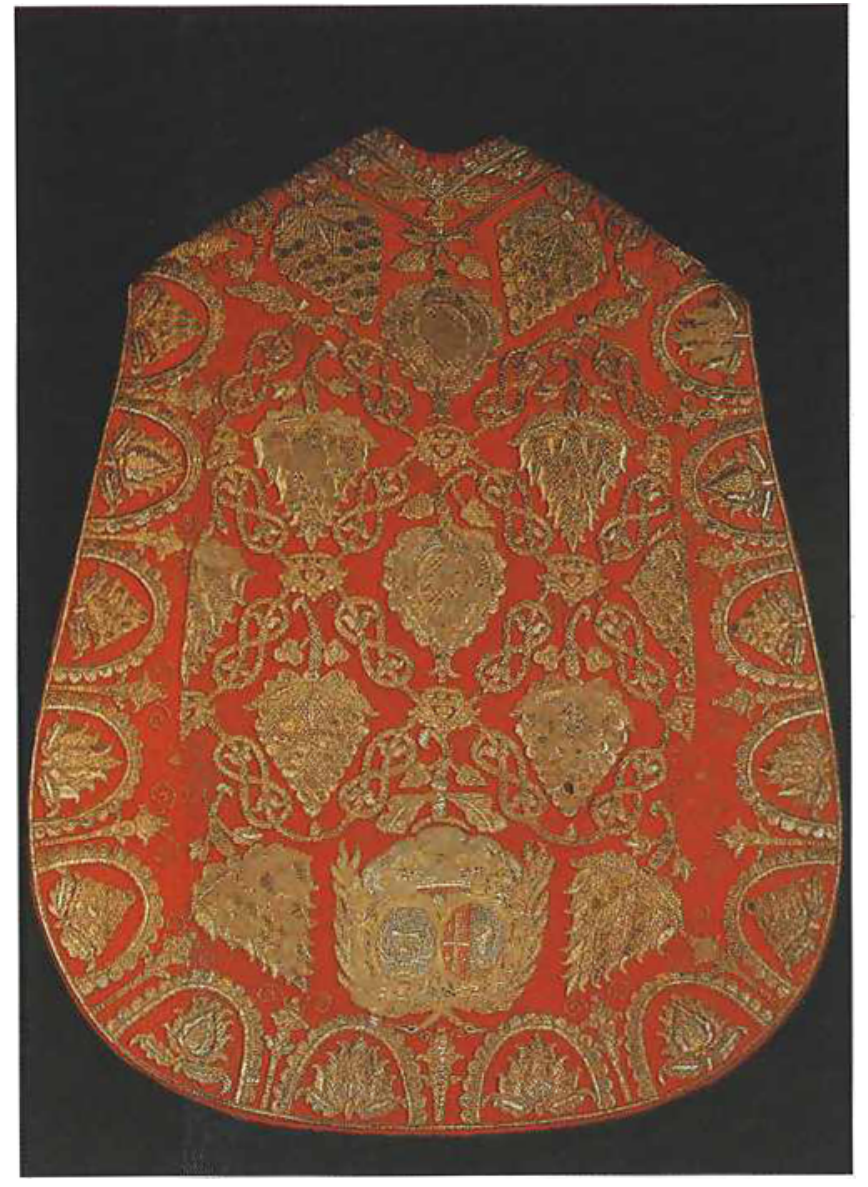

Fig. 2

Chasuble

embroidered with gold thread

(17 th century)

\section{Scientific investigational techniques}

Art historical studies of gold-threaded textiles can be very well complemented by the scientific investigation of gold threads:

- Morphology tests carried out by optical microscopy and scanning electron microscopy permit one, in addition to determining the type and dimensions of the thread, to observe the technique used for manufacture of the metal strip or wire. In the case of strips wound around a fibrous core, one can also see the method of winding (twist, sparse, dense, etc.), colour, material, twist of the fibrous core, etc. With

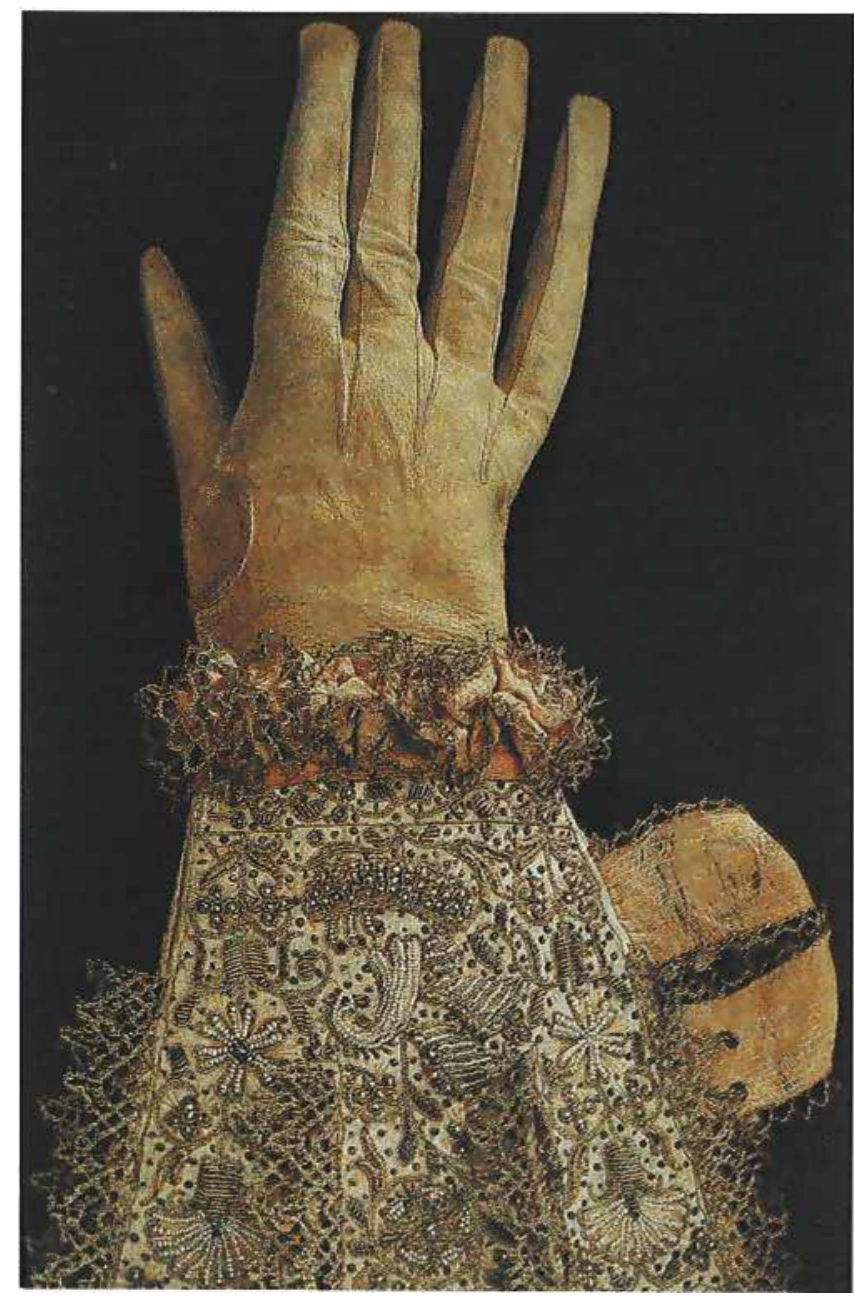

Fig. 3

Gloves with gold lace and embroidery

(17th century) 
membrane threads, in addition to the above, the organic support (animal gut, leather, etc.) can often be identified.

- Material tests carried out by various physico-chemical methods, e.g. atomic emission spectroscopy, laser-microspectral analysis, X-ray fluorescence, electron probe microanalysis, neutron activation analysis, can be of help in determining not only the composition of the metal but often the mode of gilding as well.

Publications on textile history mostly contain little information touching on metal threads [1], and more rigorous research has been carried out only on some specific finds [2]. Disregarding some earlier, comprehensive works $[3,4]$ comparative study of the origin and techniques of manufacture of metal threads based on analytical data started only during the late $1970 \mathrm{~s}$ and early 1980s [5]. The available analytical data are by no means sufficient to reconstruct all the medieval metal thread manufacturing techniques, nor do they establish where, when and how the making of the different kinds of metal threads started. They have, however, not only expanded our knowledge significantly, but have also raised new problems with the result that unanswered questions are multiplying.

Before outlining what has already been achieved, and what remains to be achieved in the research into the gold threads used in Europe from the 11th to the 14th centuries, let us first look at what kind of gold threads were utilized for decorating textiles up to the end of the first millennium.

\section{Gold threads on early medieval textiles in Europe}

Textiles from the early medieval period are to be found primarily in tombs; they are fragmentary. In the 5th to 8th centuries, it was mostly strips cut from gold foils that were used to make braids for decorating cloth [6]. Among the exceptions, we might mention the gold wires found in a Frankish tomb in Cologne [7] or the thread made from gold strip wound around a silk core excavated from Queen Arégonde's tomb in St. Denis, France [8]. According to Petraschek-Heim [9] the wires and the strips wound around a fibrous core might have been imported from the East at that time.
Fig. 4

Detail of the gold embroidery on the collar of the Hungarian coronation mantle (12th century) [36]
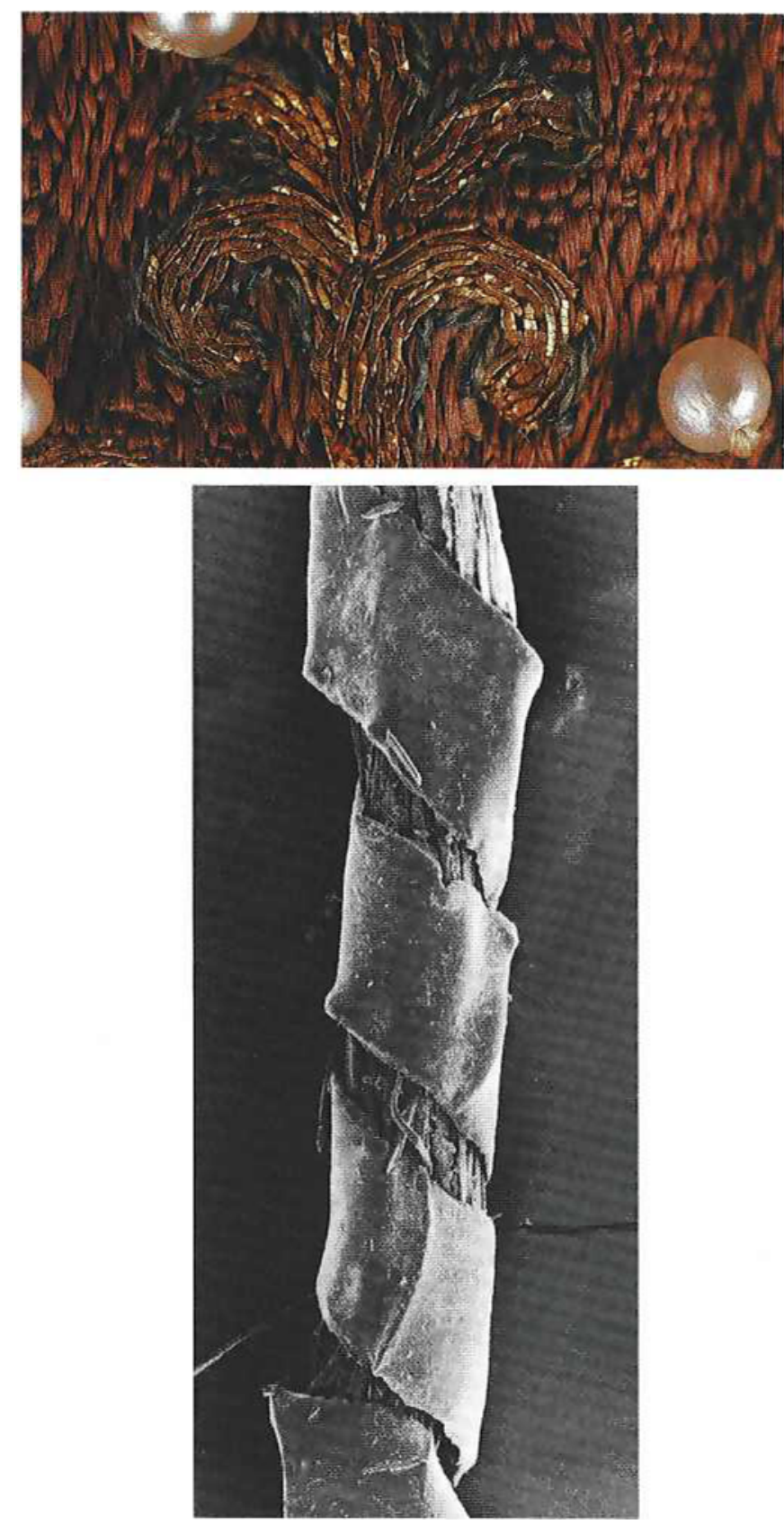

Fig. $4 a$

Scanning electron micrograph of the gold thread (gold strip wound around a silk core; width of strip: $0.20 \mathrm{~mm}$ ) [37] 


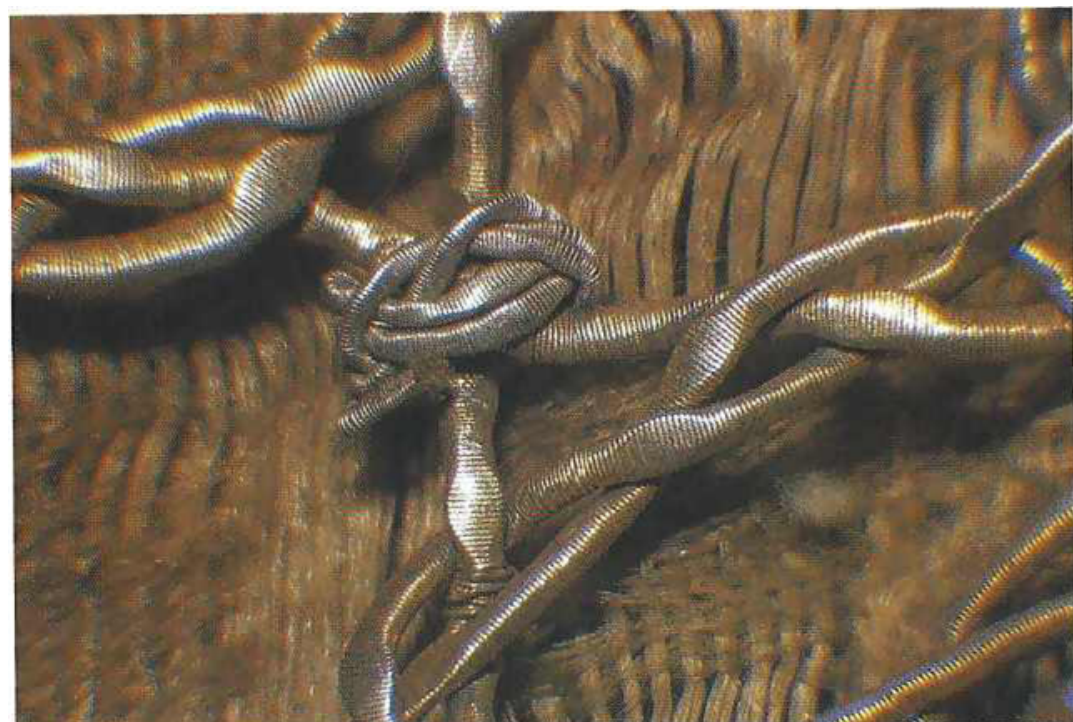

Fig. 5

Detail of the gold lace on a Turkish horse-cloth

(17th century)
Fig. $5 a$

Scanning electron migrograph of the gold thread (gilt silver wire wound around a silk core; diameter of wire: $0.10 \mathrm{~mm}$ )

[37]

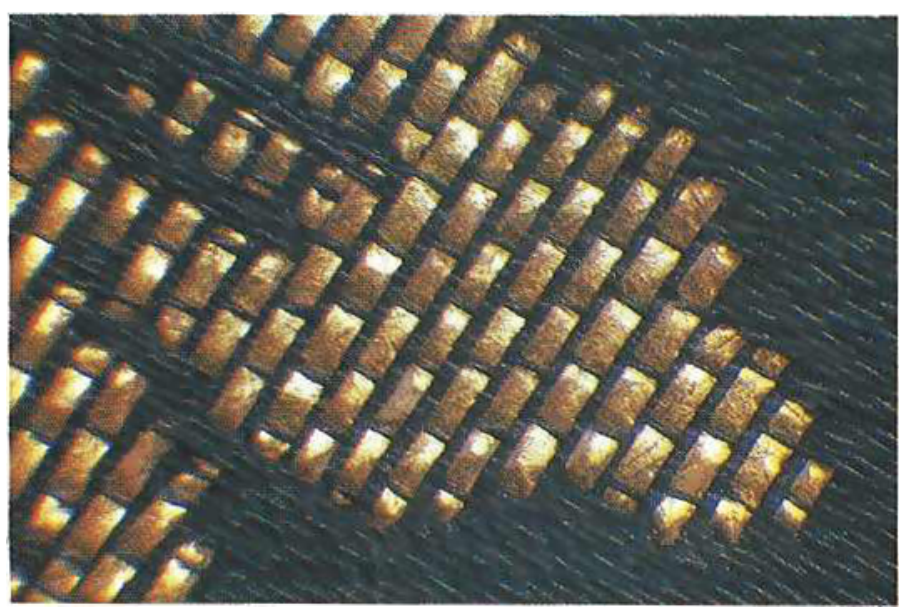

Fig. 6

Detail of a textile fragment interwoven with membrane thread (gilt paper strip; 18th-19th century)

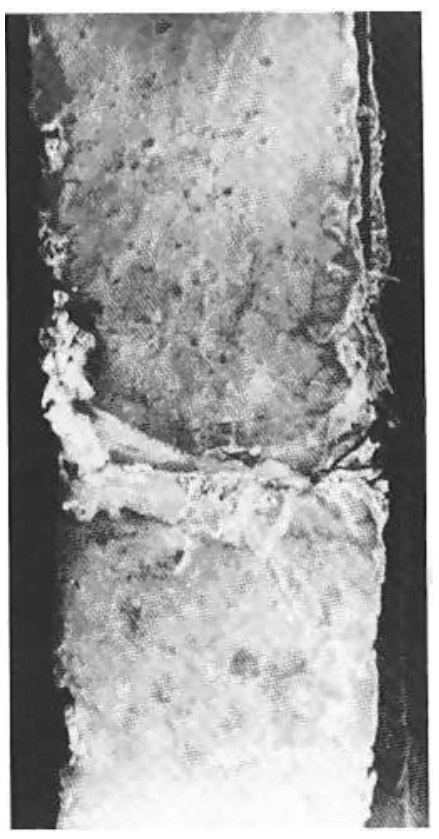

Fig. 6a

Scanning electron micrograph of the gold thread (width of strip: $0.30 \mathrm{~mm}$ ) [37] 


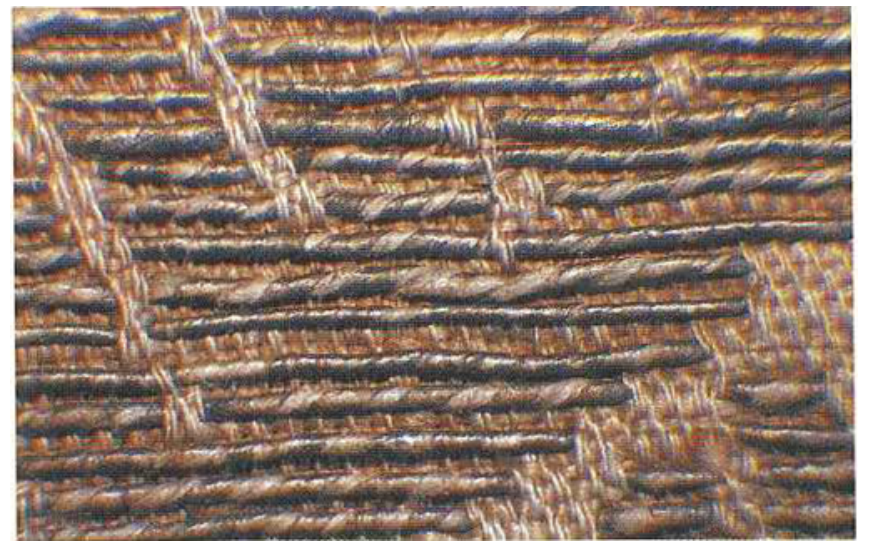

$$
\begin{gathered}
\text { Fig } 7 a \\
\text { Scanning electron } \\
\text { micrograph of the gold thread } \\
\text { (width of strip: } 0,70 \mathrm{~mm} \text { ) [37] }
\end{gathered}
$$

Fig. 7

Detail of a textile fragment interwoven with membrane thread

(silver gilt animal gut wound around a linen core;

14 th century).

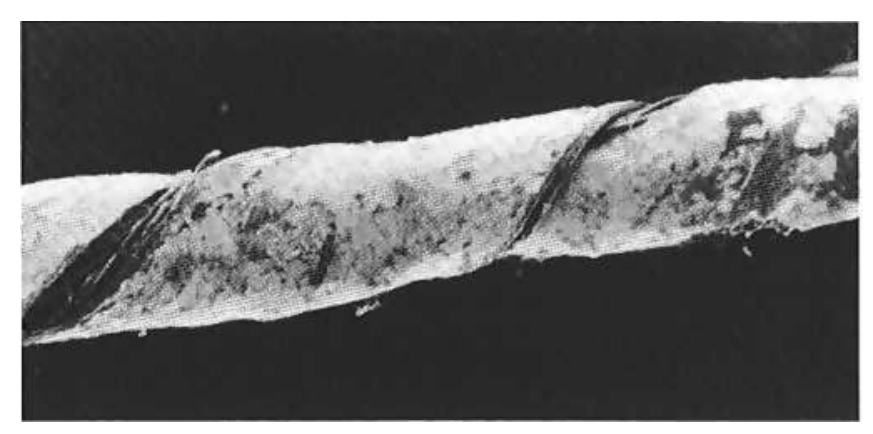

In the 9th and 10th centuries, metal threads made of gold strips wound around a fibrous core seem to have been the types most commonly used [10]. One of the exceptions is the metal thread from Traismauer (Austria) made from gilt silver strip wound around a fibrous core [11].

\section{Gold threads}

\section{on 11-14th centuries textiles in Europe}

In the 11 th to the 14 th centuries, threads made by winding solid metal strips around a silk core or membrane threads were the types most commonly used in gold embroidery and in woven gold fabrics.

\section{Gold threads \\ made from gold strip wound around a silk core}

Most art historians state that gold threads (Fig. 8) made with the traditional manufacturing technique mentioned in the Bible, were used at the beginning of the 2nd millennium. This involved cutting thin gold foil strips and winding them around a silk core [12].
The rather scarce, secular or ecclesiastic, mainly embroidered, gold threaded textiles from the 11-14th centuries, are among the most precious treasures of European museums. Gold threads of but a few of them have been subjected to systematic morphological and material tests. The data obtained by the investigations up to now can neither confirm nor contradict the art historians' statement mentioned above, but a number of questions arise. If we can answer them, we will possibly gain a clearer picture about the metal thread manufacture of this period.

In Table 1 the results of our investigations and the few published data available to me are summarized. Data which can more or less be compared with one another were collected. The morphologically uniform threads were made by winding a solid metal strip around a silk core. The thickness of the metal threads is not felt to be characteristic (in certain cases the embroidery had been hammered down; the metal strip might have become loose or unwound in use or when sampling), so this parameter has been omitted from the table. The metal thread from the Bamberg textile was analysed by classical microchemical methods, the others by neutron activation analysis.

Tabulated data show that very narrow strips made of pure gold or of gold alloyed with a small amount of silver were used for making threads for embroidery. 
Fig. 8

Embroidery thread from the

Hungarian coronation mantle

(11th century;

width of gold strip: $0,25 \mathrm{~mm}$ )

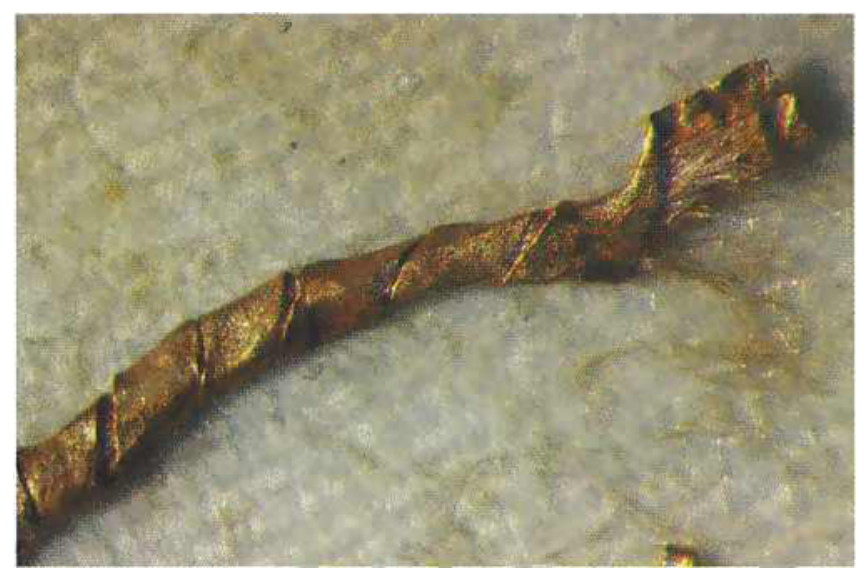

The first question that arises is:

\section{- How and where were these gold threads made?}

The making of gold foil is described in several medieval sources (e.g. Papyrus Leiden, Lucca Manuscript, Diversarum Artium Schedula). If these palm-size foils were utilized to make gold threads, the fitting of the roughly $10 \mathrm{~cm}$ long strips cut from them took a lot of time since kilometres of thread had to be made.

For every centimetre of the Hungarian coronation mantle, about 60 metal threads were fitted and sewn together (couching technique) [16]. Thus, $1 \mathrm{~cm}^{2}$ of the embroidery was made with a metal thread about $60 \mathrm{~cm}$ long, consuming about triple the amount of wound metal strip. Embroidery of the mantle surface (about $3 \mathrm{~m}^{2}$ ) consumed a metal strip of over $50 \mathrm{~km}$ in length. If it was made by fitting strips cut out of palm-size foils,

Table 1

Morphological and material test results of medieval gold threads

made of gold strip wound around a silk core

\begin{tabular}{|c|c|c|c|c|c|c|c|c|c|}
\hline \multirow{2}{*}{$\begin{array}{l}\text { Textile } \\
\text { (Location) }\end{array}$} & \multirow[t]{2}{*}{ Origin } & \multirow[t]{2}{*}{ Century } & \multicolumn{3}{|c|}{ Metal Strip Material } & \multicolumn{2}{|c|}{ Metal thread } & \multirow{2}{*}{$\begin{array}{l}\text { Colour } \\
\text { of the core }\end{array}$} & \multirow[t]{2}{*}{ Ref. } \\
\hline & & & $A u \%$ & $\mathrm{Ag} \%$ & Cu\% & $\begin{array}{l}\text { Width } \\
\text { (mm) }\end{array}$ & $\begin{array}{l}\text { Wrapping } \\
\text { Twist }^{1}\end{array}$ & & \\
\hline $\begin{array}{l}\text { Henry II's tunic } \\
\text { (Bamberg) } \\
\text { embroidered galloon }\end{array}$ & German & $\begin{array}{l}\text { 11th } \\
\text { 1st quart }\end{array}$ & 95,41 & 3,81 & $\begin{array}{l}\text { no } \\
\text { data }\end{array}$ & 0,6 & $\begin{array}{l}\text { no } \\
\text { data }\end{array}$ & yellow & 13 \\
\hline $\begin{array}{l}\text { Hungarian coronation } \\
\text { mantle } \\
\text { (Budapest) }\end{array}$ & Hungary? & $\begin{array}{c}11 \text { th } \\
\text { 1st half }\end{array}$ & 97.6 & 2.0 & 0.4 & $0.3-0.35$ & $S$ & pinkish & 14 \\
\hline strap of the mantle & ? & $\begin{array}{l}\text { latest in } \\
\text { the 12th }\end{array}$ & 99.4 & 0.5 & 0.4 & $0.26-0.30$ & S & pinkish & 14 \\
\hline $\begin{array}{l}\text { collar of the mantle } \\
\text { couched metal thread }\end{array}$ & Hungary? & $\begin{array}{l}\text { 12th } \\
\text { 2nd half }\end{array}$ & 90.2 & 7.1 & 2.6 & $0.20-0.25$ & $\mathrm{~S}$ & white & 14 \\
\hline $\begin{array}{l}\text { collar of the mantle } \\
\text { filigree }\end{array}$ & Hungary? & $\begin{array}{l}\text { 12th } \\
\text { 2nd half }\end{array}$ & 88.7 & 9.1 & 2.1 & $0.20-0.25$ & S & white & 14 \\
\hline $\begin{array}{l}\text { Episcopal shoes } \\
\text { (Lyon) }\end{array}$ & $\begin{array}{l}\text { Byzantium } \\
\text { Spain }\end{array}$ & 11 th-12th & 84.7 & 13.1 & 2.2 & 0.10 & $\mathrm{~S}$ & white & 15 \\
\hline
\end{tabular}

1 The wrapping twist of a metal thread can be characterized, similarly to that of textile yarns, by the letters $\mathrm{S}$ or $\mathrm{Z}$ (see here):

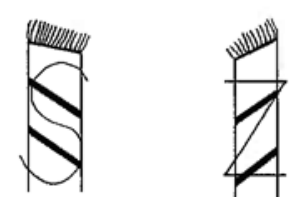


over half a million fittings would have been needed. It seems more likely that either foils were first fitted to a band of some length and then cut into strips, or wider bands hammered from bars were cut to narrower ones [17].

However, the evidence for both of these latter methods seems rather circumstantial. It appears to be much more likely that drawn wire, already known in the early Middle Ages [18], was used to make the metal strip - at least in most cases [19].

Investigations of these threads lead to further questions:

\section{- What kind of tools were used for cutting foils into strips?}

If a great many cut strips were to be examined, perhaps we could decide whether scissors-like tools, blades or other tools were utilized.

\section{- By what method was the strip wound around the core?}

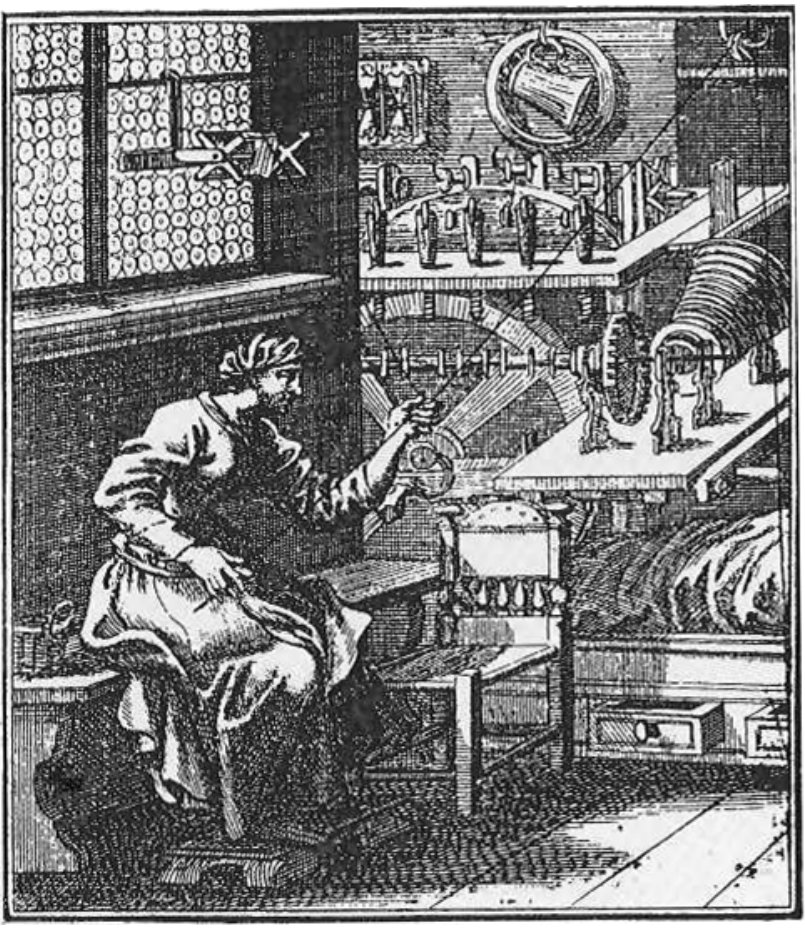

Fig. 9

A woman spinning gold thread. Copperplate engraving from "Etwas für Alle", Part II, by Abraham a Santa Clara, Wiurzburg, 1711 [38] (for example an embroidered burial stole from the 13th century; Italian brocaded silk from the 14th century) but no investigational data are given. In this period, metal threads had already been prepared probably from gilt silver rather than from pure gold or gold alloy.

\section{Gold threads made of gilt silver}

The majority of art historians date the appearance in Europe of metal threads made from gilt silver strips to the 13 th or 14 th century, when these strips were made by gilding rods of silver. From these, wires were drawn and flattened [21], so that both sides of the metal strip were coated with gold [22]. In Fig. 10 such a gilt silver thread is seen, Fig. 11a and b shows the elemental composition of the surface and of the back of the metal strip. No difference in the composition could be detected. In general, no mention is made of the gilt silver thread described by Theophilus Those metal strips we have tested up to now have been fairly uniformly wound; there was no case of a turned or twisted metal strip. Presumably some device was used to guide the strip and core even in these early times, as seen from an 18 th century etching (Fig. 9). To the best of my knowledge, no contemporary description or drawing is known of such a tool.

I am not aware of the existence of any test data on metal threads made with pure gold or gold alloy strips from 13-14th century gold embroidery or weaving. Flury-Lemberg [20] mentions some pieces from this period made with gold strips wound around a silk core
Presbyter (12th century). He describes how silver and gold foil can be soldered to each other and hammered to a narrow band. From this band, fine strips could be cut for winding around silk yarn:

$$
\begin{gathered}
\text { "These are woven to aurifrigiums } \\
\text { for poor people } \\
\text { in the same way as for the rich, } \\
\text { only } \\
\text { that for these latter, } \\
\text { they are of pure gold" } \\
\text { [23]. }
\end{gathered}
$$


For metal threads made by this method, only one side of the metal strip is gold coated as can be seen in Figs. 12 and 13a-b.

King's data [24] show that English embroideries (Opus Anglicanum) were made with gilt silver threads from the 11 th century onward. This means that the use of these types of metal threads began earlier in Europe. This statement can also be supported by the fact that some pieces of textile restored by Flury-Lemberg, dated to the 12th century, were also decorated with gilt silver threads [25].

In Table 2 the results of the investigations of Hoke and PetraschekHeim [26], Darah [27], Indictor et al. [28] and of ourselves [29] are summarized. If we wish to compare the data, we should take into consideration the fact that the results of analyses are given in different ways. Together with Hoke and Indictor, we measured the main element concentration of the silver layer (on the back of the strip) by energy dispersive X-ray analysis (microprobe); Darah used the same analytical method but gives the ratio of the detected main components not indicating which side of the strip (surface or back) was analysed. For comparison, a silver-to-copper ratio is given (as suggested by Hoke).

Hoke et al. distinguished European and Easternmade metal threads by the copper content of the silver. They have found the silver-to-copper ratio in European metals to be lower than in Eastern ones and suggest that an upper limit of 20 be taken for it. Darah's, Indictor's and our data seem to be in agreement with this provenance attribution.

No data up to now indicate the use of strips made by the flattening of gilt wires in this period, or that the method of gilding the silver wire was other Fig. 10

Gold thread from a fringe (19th century; width of metal strip: $0,25 \mathrm{~mm}$ ) than that described by Baker [22]. All the examined threads dated to the 11-14th centuries were of

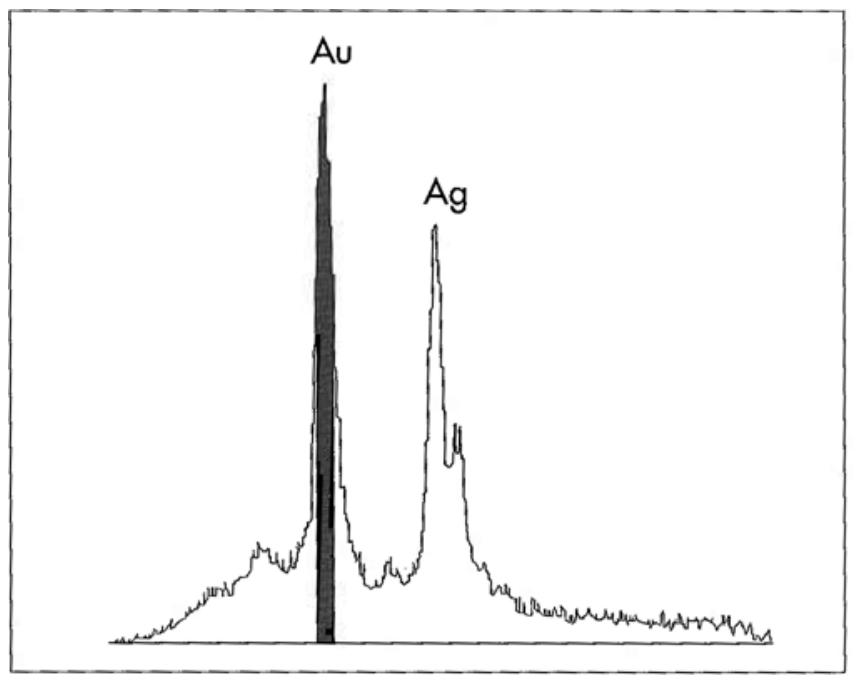

Fig. 11a

Elemental composition of the surface of the gold thread seen in Fig. 10

[39]

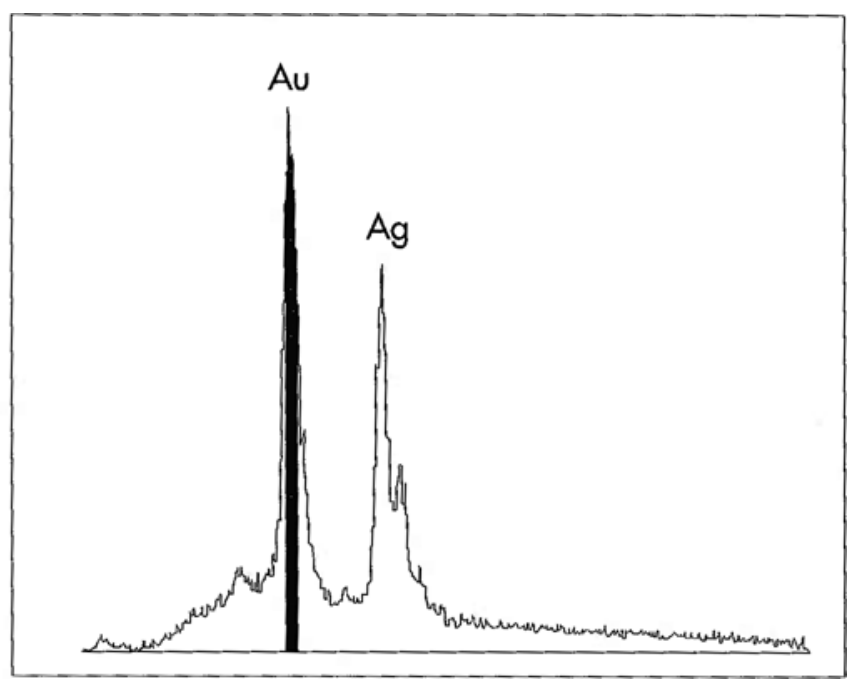

Fig. $11 b$

Elemental composition of the back of the gold thread seen in Fig. 10 [39] 
Table 2

Morphological and material test results of medieval gold threads made of gilt silver strip wound around a silk core

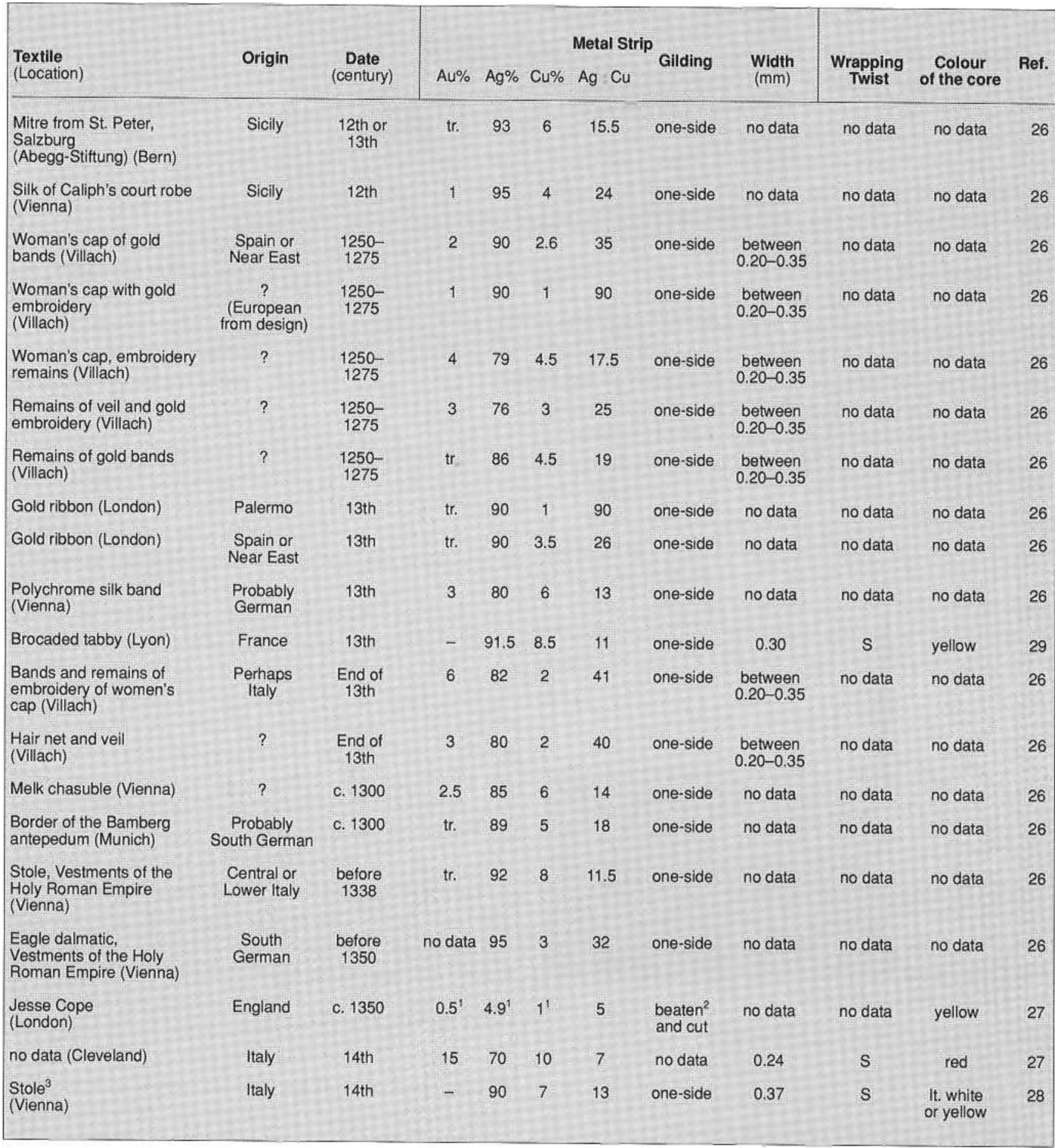

1 Ratio of the elements is given not the true proportion

2 Beaten and cut means that the strip was cut from a foil, and in this case it could be gilded on one side

${ }^{3}$ Possibly the Stole analysed by Indictor is the same as that examined by Hoke 
silver gilded on one side only. arises:

Thus, the question

- How was the silver used for making strips gilded in this early period?

The distribution of the different elements on the cross-section of one-sided gilded silver strips on the one hand, and trace element analysis verifying the presence of mercury, on the other, might give an answer to this question.

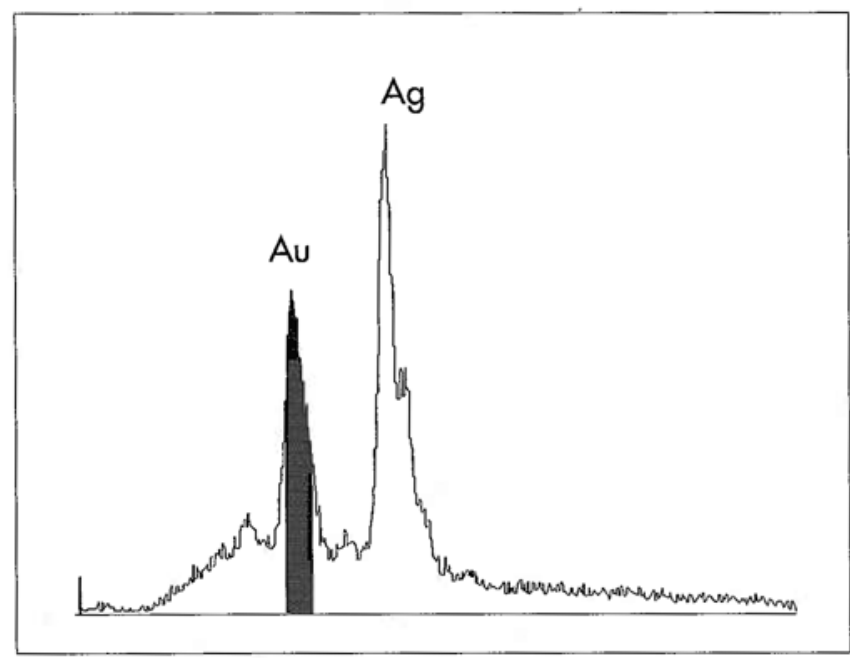

Fig. 13a

Elemental composition of the surface of the gold thread seen in Fig. 12 [39]

The second question is:

- When did gilt silver strips made of drawn wire appear in Europe?

Further, systematic analyses of accurately dated gilt silver strips are needed to answer this question.
And there still remains the problem of the origin of the different types of gilt silver strips. This poses the question:

- Where were the different types of gilt silver strips (differently gilded silver) first manufactured?

Fig. 12

Gold thread from a pouch (10th century, width of metal strip:

$0.20 \mathrm{~mm}$ )

In addition to answering the above questions, we also need a great deal of data derived from investigations carried out on metal threads of precise

date and origin.

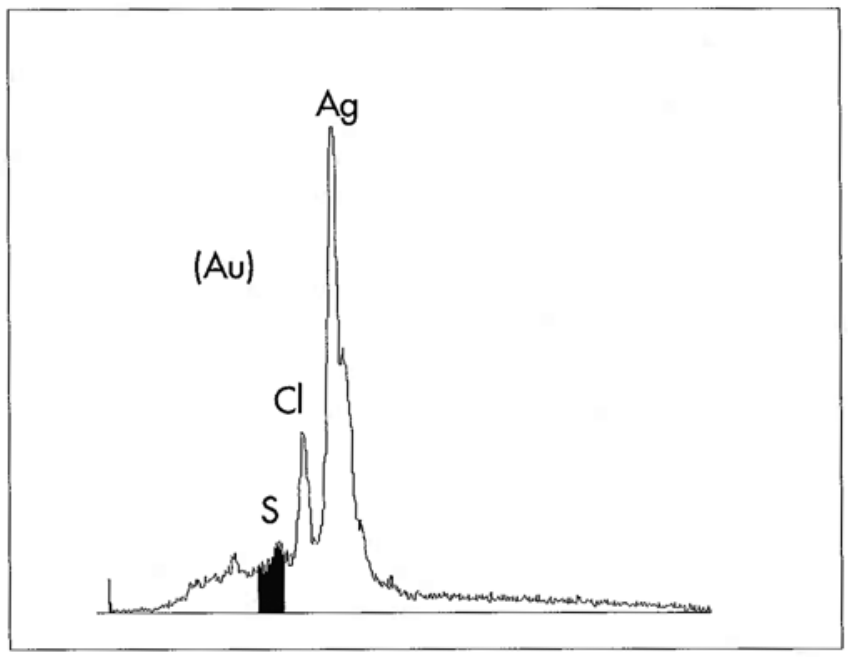

Fig. 13b

Elemental composition of the back of the gold thread seen in Fig. 12 [39]

\section{Gold membrane threads}

Membrane threads (Figs. 14a and 15a), referred to in publications as Cyprus gold threads - "gold-saving" threads of an ingenious concept - began to spread in the 11 th century, according to some researchers, whereas others hold that this happened only in the 12th century [30]. Flexible thread eased the weaving process; 


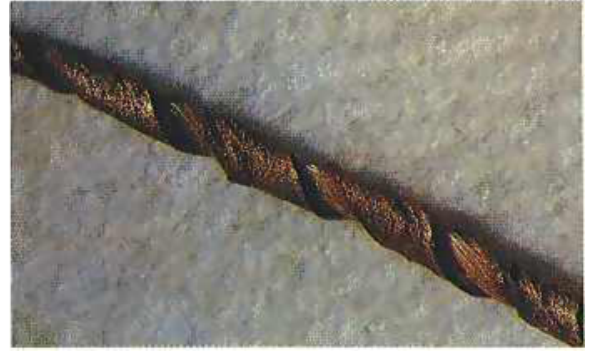

Fig. 14a

Membrane

thread: gilt

leather strip

wound around a

silk core. (strip

width: $0.40 \mathrm{~mm}$ )

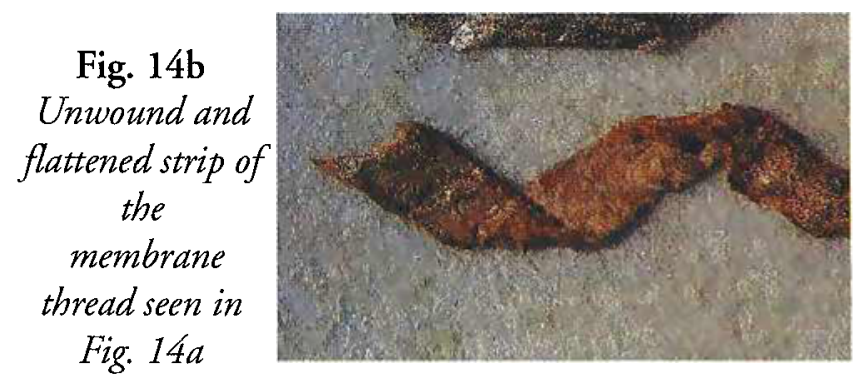

it reduced the weight of clothing or fabric, and - last but not least - it decreased the cost.

Initially, the novel-type metal thread (or the metal threaded textile) was imported from the East, from Byzantium or possibly from Western Asian regions by ships calling in at the ports of Cyprus (hence its earlier name), or from North Africa across to Southern European ports. In Asia it had been rather popular; in China and Japan membrane threads made with gilded paper strips (Fig. 6) are still in use. In the 12-14th centuries its use, mainly for weaving, was common in Southern and Central Europe. From about the 13-14th centuries it was also produced in European workshops. In embroidery, it seldom occurs, but if it does it is mainly after the mid-14th century. With the spreading of gilt silver threads, it gradually became replaced.

Early fabrics from the 11-13th centuries, woven with membrane threads, are curiosities of textile collections, just as are items made with solid metal threads from the same period. Many more textiles (mainly fragments), made with membrane thread, are encountered from the 13-14th centuries.

In Table 3 Indictor's [31], Darah's [27] and our [32] data on membrane threads are given. For a possible comparison threads originating from outer Europe are also included. Tests were carried out by different methods. Indictor and Darah used energy dispersive X-ray analysis and so did we in the case of samples L-44, L-45 and L-46. In other cases, we analysed the metal layer by atomic emission spectrography. The term "membrane" in Table 3 means animal gut. The identification of the support sometimes causes problems. When the organic layer is transparent it can be considered as animal gut (Fig. 15b). When it is not, its colour is brownish, and it is not so thin; it could be leather (Fig. 14b), parchment, paper or some kind of thicker animal gut.

The back of the strip shows the structure of the organic support (Figs. 16 and 17). The silver-to-copper ratios given are only for orientation; they do not reflect the true proportions of the two elements, especially in cases where gilt silver was used and the silver is corroded.

On the basis of the data, membrane threads earlier referred to by the collective name "gold threads from Cyprus" could be differentiated by the manufacturing technique. We can find among them metal-coated leather and animal gut strips. The metal layer is, in some cases, of pure gold; in other cases, gold alloyed with a smaller amount (or traces) of silver, or a larger amount of silver with gold. The strips are wound around different kinds of fibrous core (silk, linen, cotton) in an $S$ or a $Z$ twist.

Based on the manufacturing technique, we can distinguish several types of membrane threads - as shown in Table 4.

The classification is often uncertain (for instance because of the identification difficulties regarding the support material). A unified investigation method of the

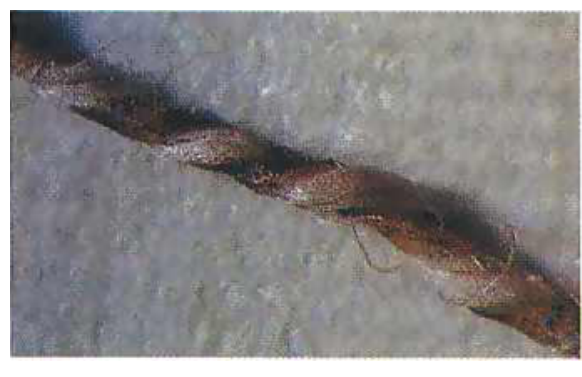

Fig. 15a Membrane thread: silver gilt animal gut strip wound around $a$ linen core. (strip width: $0.25 \mathrm{~mm}$ )

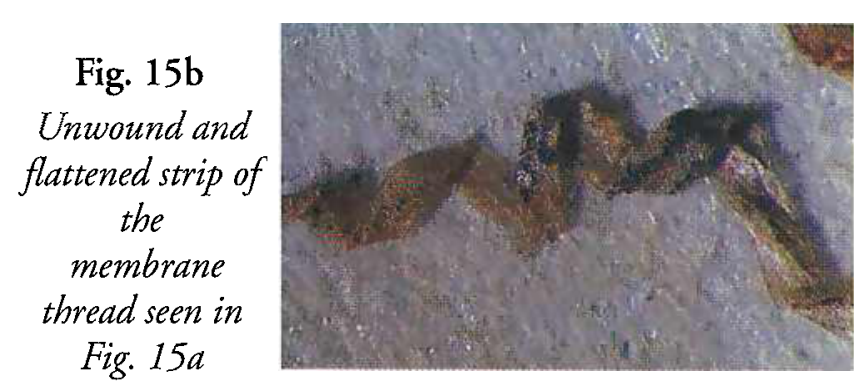


Table 3

Morphological and material test results of medieval membrane threads

\begin{tabular}{|c|c|c|c|c|c|c|c|c|c|}
\hline \multirow[b]{2}{*}{$\begin{array}{l}\text { Textile or } \\
\text { Lab. No. }\end{array}$} & \multirow[b]{2}{*}{ Origin } & \multirow[b]{2}{*}{$\begin{array}{l}\text { Date } \\
\text { century }\end{array}$} & \multicolumn{3}{|c|}{ Metal coated Strip } & \multirow[b]{2}{*}{$\begin{array}{l}\text { Wrapping } \\
\text { Twist }\end{array}$} & \multicolumn{2}{|c|}{ Core } & \multirow[b]{2}{*}{ Ref. } \\
\hline & & & Metal layer & Support & $\begin{array}{l}\text { Width } \\
(\mathrm{mm})\end{array}$ & & Material & Colour & \\
\hline$L-45$ & Byzantium & 10 th-11th & $\begin{array}{l}\mathrm{Au} \cdot \mathrm{Ag} \\
7: 1\end{array}$ & leather & 0.45 & $z$ & silk & yellowish & 32 \\
\hline L-44 & Arabia & 10 th -12 th & $\begin{array}{l}\mathrm{Au} \cdot \mathrm{Ag} \\
10: 1\end{array}$ & leather & 0.50 & z & silk & yellow & 32 \\
\hline 29 & Italy & 12th & pure gold & membrane & no data & no data & silk & no data & 27 \\
\hline CMA 27.380 & Spain & 13th & $\begin{array}{l}\mathrm{Au}: \mathrm{Ag} \\
7.5: 2\end{array}$ & $\begin{array}{l}\text { parchment } \\
\text { or membrane }\end{array}$ & 0.47 & z & silk & light yellow & 31 \\
\hline CMA 28.650 & Spain & 13th & $\begin{array}{c}\mathrm{Au}: \mathrm{Ag} \\
8: 1\end{array}$ & $\begin{array}{l}\text { membrane } \\
\text { or parchment }\end{array}$ & 0.74 & z & silk & red and pink & 31 \\
\hline CMA 32.137 & Spain & 13th & $\begin{array}{c}\mathrm{Au} \mathrm{Ag} \\
18: 1\end{array}$ & $\begin{array}{l}\text { parchment } \\
\text { or membrane }\end{array}$ & 1.04 & $z$ & silk & light yellow & 31 \\
\hline CMA 48.498 & Spain & 13th & $\begin{array}{c}\mathrm{Au}: \mathrm{Ag} \\
1: 8\end{array}$ & leather & 0.48 & S & linen & white & 31 \\
\hline $1-7$ & Regensburg & 13th? & gilt silver & membrane & $0.30-0.40$ & s & linen & undyed & 32 \\
\hline CMA 19.28 & $\begin{array}{l}\text { Egypt or } \\
\text { Syria }\end{array}$ & 13 th-14th & pure gold & leather & 0.59 & S & silk & undyed & 31 \\
\hline $1-26$ & $\begin{array}{l}\text { Italian or } \\
\text { German }\end{array}$ & 13 th -14 th & gilt silver & membrane & $0.40-0.50$ & S & linen & undyed & 32 \\
\hline $1-27$ & $\begin{array}{l}\text { Italian or } \\
\text { German }\end{array}$ & 13 th -14 th & gilt silver & membrane & $0.30-0.40$ & $s$ & linen & undyed & 32 \\
\hline $1-6$ & German & 13 th -14 th & gilt silver & membrane & $0.20-0.30$ & S & linen & undyed & 32 \\
\hline CMA 85.4 & $\begin{array}{l}\text { West } \\
\text { Turkestan }\end{array}$ & 14 th & $\begin{array}{c}\mathrm{Au}: \mathrm{Ag} \\
1: 17\end{array}$ & $\begin{array}{l}\text { membrane } \\
\text { or leather }\end{array}$ & 0.54 & z & cotton & undyed & 31 \\
\hline CMA 29.905 & Near East & 14th & pure gold & $\begin{array}{l}\text { membrane } \\
\text { or leather }\end{array}$ & 0.42 & S & linen & undyed & 31 \\
\hline CMA 45.34 & Near East & 14th & pure gold & $\begin{array}{l}\text { membrane } \\
\text { or leather }\end{array}$ & 0.55 & s & linen & undyed & 31 \\
\hline CMA 26.509 & Near East & 14th & $\begin{array}{l}\text { gold, traces } \\
\text { of silver }\end{array}$ & membrane & 0.55 & s & linen & undyed & 31 \\
\hline KR 00135 & Near East & 14th & pure gold & $\begin{array}{l}\text { leather or } \\
\text { membrane }\end{array}$ & 0.51 & z & cotton & undyed? & 31 \\
\hline $\mathrm{CH} 02-1-273$ & Near East & 14th & pure gold & $\begin{array}{l}\text { leather or } \\
\text { membrane }\end{array}$ & 0.45 & $\mathrm{~s}$ & silk & undyed? & 31 \\
\hline $\mathrm{CH} 02-1-285$ & Near East & 14th & pure gold & membrane & 0.72 & S & linen & undyed & 31 \\
\hline CMA $18.30 \mathrm{a}$ & Near East & 14th? & pure gold & parchment & 0.97 & Z & silk & yellow & 31 \\
\hline CMA 39.44 & Near East & 14th & pure gold & leather & 0.34 & $S$ and $Z$ & linen & undyed & 31 \\
\hline
\end{tabular}


Table 3 (cont.)

Morphological and material test results of medieval membrane threads

\begin{tabular}{|c|c|c|c|c|c|c|c|c|c|}
\hline \multirow[b]{2}{*}{$\begin{array}{l}\text { Textile or } \\
\text { Lab. No. }\end{array}$} & \multirow[b]{2}{*}{ Origin } & \multirow[b]{2}{*}{$\begin{array}{l}\text { Date } \\
\text { century }\end{array}$} & \multicolumn{4}{|c|}{ Metal coated Strip } & \multicolumn{3}{|c|}{ Core } \\
\hline & & & Metal layer & Support & $\begin{array}{l}\text { Width } \\
(\mathrm{mm})\end{array}$ & $\begin{array}{c}\text { Wrapping } \\
\text { Twist }\end{array}$ & Material & Colour & Ref. \\
\hline CMA 18.292 & Near East & 14th & pure gold & $\begin{array}{c}\text { membrane or } \\
\text { parchment }\end{array}$ & $?$ & Z & silk & yellow & 31 \\
\hline KR 06109 & Near East & 14th & pure gold & leather & 0.70 & Z & silk & light yellow & 31 \\
\hline CMA 42.1077 & Spain & 14 th & $\begin{array}{l}\mathrm{Au}: \mathrm{Ag} \\
6.7: 1\end{array}$ & $\begin{array}{l}\text { leather or } \\
\text { membrane }\end{array}$ & 0.54 & $z$ & silk & light yellow & 31 \\
\hline CMA 39.42 & Spain & 14th & $\begin{array}{c}\mathrm{Au}: \mathrm{Ag} \\
2: 7\end{array}$ & leather & 0.39 & Z & silk & yellow & 31 \\
\hline$L-46$ & Sicily & 14 th & $\begin{array}{l}\text { gold, traces } \\
\text { of silver }\end{array}$ & $\begin{array}{l}\text { leather or } \\
\text { membrane }\end{array}$ & 0.50 & S & linen & undyed & 32 \\
\hline $1-33$ & Venice? & 14th & gilt silver & membrane & $0.30-0.50$ & S & linen & undyed & 32 \\
\hline $1-1$ & Venice & 14th & gilt silver & membrane & 0.30 & $\mathrm{~S}$ & linen & undyed & 32 \\
\hline $1-30$ & $\begin{array}{l}\text { Venice or } \\
\text { Lucca }\end{array}$ & 14 th & gilt silver & membrane & $0.70-1.00$ & $\mathrm{~S}$ & $?$ & $?$ & 32 \\
\hline $1-40$ & Lucca & 14th & no data & membrane & $0.70-0.75$ & $\mathrm{~S}$ & linen & undyed & 32 \\
\hline $1-12$ & Lucca & 14th & gilt silver & membrane & $0.70-0.90$ & $\mathrm{~S}$ & linen & undyed & 32 \\
\hline $1-19$ & Lucca & 14th & no data & membrane & $0.90-1.10$ & S & linen & undyed & 32 \\
\hline $11-31$ & Lucca & 14th & gilt silver & membrane & $0.60-0.80$ & $\mathrm{~S}$ & $?$ & $?$ & 32 \\
\hline $1-32$ & Lucca & 14th & gilt silver & membrane & $0.50-0.70$ & $S$ & linen & undyed & 32 \\
\hline $1-23$ & Lucca & $\begin{array}{c}\text { end of the } \\
\text { 14th }\end{array}$ & gilt silver & membrane & $0.60-0.80$ & $S$ & linen & undyed & 32 \\
\hline $1-24$ & Lucca & $\begin{array}{c}\text { end of the } \\
14 \text { th }\end{array}$ & gilt silver & membrane & $0.70-0.80$ & S & linen & undyed & 32 \\
\hline $1-4$ & Toscana & ca. 1400 & gilt silver & membrane & $0.50-0.60$ & $\mathrm{~S}$ & linen & undyed & 32 \\
\hline $1-5$ & Italy & 14th & gilt silver & membrane & $0.30-0.45$ & $S$ & linen & undyed & 32 \\
\hline$|-2|$ & Italy & 14 th & gilt silver & membrane & $0.30-0.40$ & $\mathrm{~S}$ & linen & undyed & 21 \\
\hline CMA 28.649 & Italy & 14th & $\begin{array}{l}\mathrm{Au}: \mathrm{Ag} \\
1: 8.5\end{array}$ & $\begin{array}{l}\text { parchment } \\
\text { or membrane }\end{array}$ & 0.87 & $\mathrm{~S}$ & linen & undyed & 31 \\
\hline CMA31.61 & Itay & 14th & $\begin{array}{c}\mathrm{Au}: \mathrm{Ag} \\
3: 5\end{array}$ & $\begin{array}{l}\text { parchment } \\
\text { or membrane }\end{array}$ & 0.54 & $\mathrm{~S}$ & linen & undyed & 31 \\
\hline 2 & Italy & 14 th & $\begin{array}{c}\mathrm{Au}: \mathrm{Ag}: \mathrm{Cu} \\
2: 1: 45\end{array}$ & membrane & no data & no data & linen & no data & 27 \\
\hline $1-25$ & German & 14 th & gilt silver & membrane & $0.50-0.60$ & $\mathrm{~S}$ & linen & undyed & 32 \\
\hline $1-10$ & German & 14 th & no data & membrane & $0.25-0.30$ & $\mathrm{~S}$ & linen & undyed & 32 \\
\hline $1-34$ & German? & 14th & no data & membrane & 0.30 & S & linen & undyed & 32 \\
\hline
\end{tabular}


membrane and of the metal composition could resolve this problem in the future.

There are samples which cannot be included in these types:

- leather or animal gut with gold or gilt silver layer wound around cotton core (samples: KR 00135 and CMA 85.4);

- leather with gilt silver layer wound around linen or silk core (samples: CMA 48.498 and CMA 39.42);

- animal gut with gold alloyed with silver wound around linen core (sample: 1);

- animal gut with metal layer containing a large amount of copper and some silver and gold (sample: 2).

In spite of the information we obtained by studying the membrane threads there are still some important questions not yet answered:

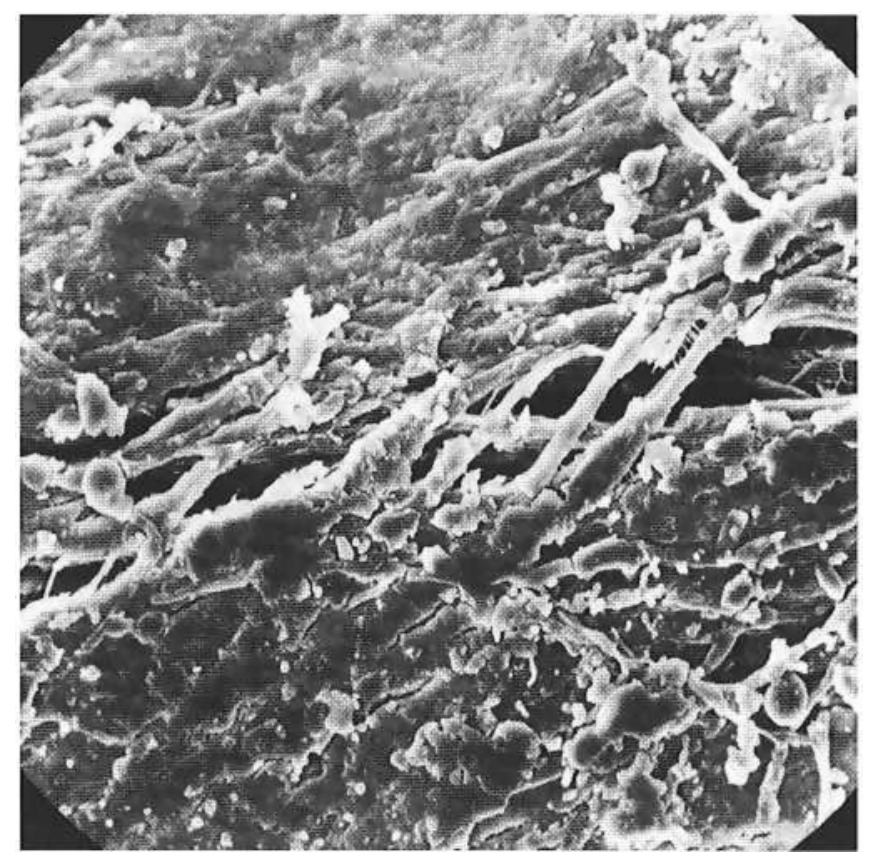

Fig. 17

Scanning electron micrograph of the back of an animal gut strip, $x 1000 \varnothing$

[37]

Fig. 16

Scanning electron micrograph of the back of a leather strip, $x 1000$ [37]

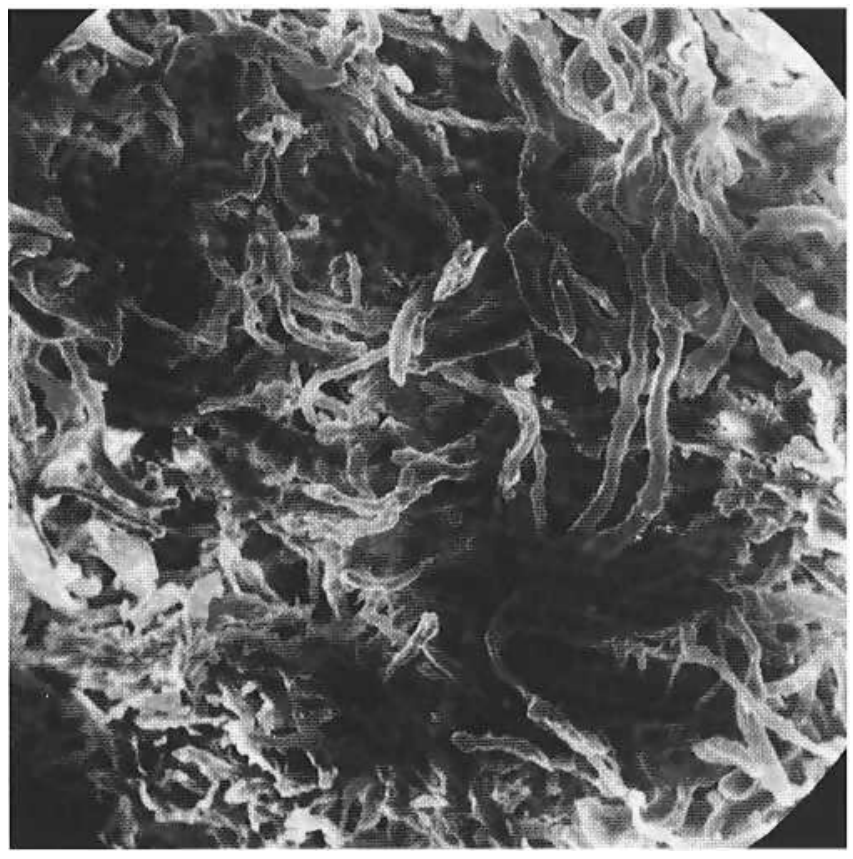

\section{- How was the leather or parchment gilded?}

On the surface of leather or parchment strips we can find pure gold or gold-silver alloy (except for type 4a, if they are parchment and samples CMA 48.498 and CMA 39.42). We can suppose that some kind of binder (e.g. egg yolk) was used for joining either gold foil [33] or gold powder [34] to the surface of the organic support, but the identification of the binding media and the reconstruction of the process are still to be done.

\section{- How was the animal gut gilded?}

On the surface of animal gut strips, gold alloyed with silver or gilt silver can be identified. What was the method for joining the metal sheet or powder to the surface? How did the early craftsmen carry out the silvering and gilding of the same surface? Research is going on to clarify this problem. 
- What were the tools for strip cutting?

Just as for solid metal strips, the width of metal-coated strips for membrane threads is often less than a quarter of a millimetre.

\section{- How was the metal-coated strip wound around the core?}

For a part of the threads, this method seems to be the same as for threads made with solid metal strips. In other cases, however, the strip could hardly be separated from the core, thereby suggesting co-winding, i.e. the core yarn was fastened at a point and was then twisted together with the strip, manually or by some device, possibly while wet [35].

There is another problem concerning winding:

\section{- Is there some technological or other explanation for the fact that the threads on linen cores are almost ex- clusively of $S$ twist?}

Except for the threads belonging to type 3 (where the organic support could be leather as well) all of the investigated membrane threads made of animal gut wound around a linen core are $S$ twist, while leather strips are mostly $Z$ twist. One wonders whether this fact can be attributed to the bast fibres having a natural spiral movement, namely that in one direction they are easier to spin than in the other? A single linen thread will usually be $S$ spun.

Examination of membrane threads raises another question:

\section{- Might membrane threads be assigned to ages or terri- tories by differences of manufacturing technique?}

There are a great many uncertainties in determining age and origin of fabrics woven or embroidered with membrane threads. Metal thread test results could contribute to a more exact categorization, if an adequate number of test results for metal threads from exactly dated
Table 4

Differentiating the membrane threads on the basis of their manufacturing technique

\begin{tabular}{|c|c|c|c|c|}
\hline $\begin{array}{l}\text { Type } \\
\text { No. }\end{array}$ & $\begin{array}{l}\text { Support } \\
\text { material }\end{array}$ & $\begin{array}{l}\text { Metal layer } \\
\text { composition }\end{array}$ & $\begin{array}{l}\text { Fibrous } \\
\text { core }\end{array}$ & Sample Nos. \\
\hline 1 & $\begin{array}{l}\text { leather or } \\
\text { parchment }\end{array}$ & $\begin{array}{l}\text { gold or gold } \\
\text { alloyed with } \\
\text { silver }\end{array}$ & $\begin{array}{l}\text { silk } \\
\text { silk }\end{array}$ & $\begin{array}{c}\text { L-45, L-44, CMA } 19.28 \\
\text { CMA } 30 \text { a, Kr } 06109\end{array}$ \\
\hline 2 & $\begin{array}{l}\text { leather or } \\
\text { animal gut }\end{array}$ & $\begin{array}{l}\text { gold or gold } \\
\text { alloyed with silver }\end{array}$ & silk & $\begin{array}{l}29, \mathrm{CH} 02-1-273 \\
\text { CMA } 42.1077\end{array}$ \\
\hline $2 a$ & $\begin{array}{l}\text { parchment or } \\
\text { animal gut }\end{array}$ & $\begin{array}{l}\text { gold alloyed } \\
\text { with silver }\end{array}$ & silk & $\begin{array}{l}\text { CMA } 27.380, \text { CMA } 28.650 \\
\text { CMA } 32.137, \text { CMA } 18.292\end{array}$ \\
\hline 3 & $\begin{array}{l}\text { leather or } \\
\text { animal gut }\end{array}$ & gold & linen & $\begin{array}{c}\text { CMA } 39.44, \text { CMA } 29.905 \\
\text { CMA } 45.34, \mathrm{~L}-45 \\
\text { CMA } 26.509 \text { CH } 02-0-285\end{array}$ \\
\hline 4 & animal gut & gilt silver & linen & $\begin{array}{c}\text { I-7, I-25, I-27, I-6, I-33, I-1, } \\
\text { I-30, I-40, I-12, I-19, I-31, } \\
\text { I-32, I-23, I-24, I-25, I-10, } \\
\text { I-34, I-4, I-5, I-21 }\end{array}$ \\
\hline $4 a$ & $\begin{array}{l}\text { animal gut } \\
\text { or parchment }\end{array}$ & gilt silver & linen & CMA 31.61, CMA 28.649 \\
\hline
\end{tabular}

fabrics assignable to given workshops or towns, were available.

At the moment, only hypotheses can be forwarded. For instance, it can be observed that membrane threads, assumed to be of Eastern origin (Byzantium, Near East, etc.) were almost exclusively made with direct gilding, without a silver layer, and the support was mostly leather. Threads were mostly wound around a silk core that could be produced at that time in those territories because of the Chinese links.

In Italian and German workshops, membrane threads of silver gilt animal gut wound around a linen core were used almost exclusively. The use of flax as core material in European workshops might be attributed to the lack of silk.

Scientific investigation, together with morphological and analytical tests of metal threads not only brings us nearer to a knowledge of skills in ancient times but could also be of help in dating and determining the origin of metal-threaded textiles. At the same time, the new questions that have arisen are helping to determine the direction of further research. 


\section{Acknowledgments}

The portrait of Elizabeth I (Fig. 1) is reproduced by courtesy of the National Portrait Gallery, London.

\section{Notes and references}

1. For example,

O. v. Falke, "Kunstgeschichte der Seidenweberei',

Berlin, 1921;

E. Flemming, 'Textile Künste', Berlin, 1923;

A.C. Weibel, 'Two Thousand Years of Textiles',

New York, 1952;

H. Schmidt, 'Alte Seidenstoffe', Braunschweig, 1958;

A. Geijer, 'A History of Textile Art', Pasold Research Fund, W.S. Maney, Leeds, 1979

2. For example,

A. Geijer, 'Birka III. Die Textilfunde aus den

Gräbern', KVHAA 1938, Uppsala;

R. Pfister, 'Textiles de Palmyre III', Paris, Les Editions d'Art et d'Histoire, 1940;

C.F. Battiscombe, 'The Relics of St.-Cuthbert', Oxford, 1956;

I. Petraschek-Heim, 'Textilkundliche Untersuchungen von Stickereien aus Grab I. in der Stadtpfarrkirche von Traismauer', Fundberichte aus Österreich, 16, 1977, Wien, 1978;

M. Fleury, A. France-Lanord, 'La tombe d'Arégonde, Dossiers de l'Archéologie', 32 (janvierfévrier), 1979

3. F. Bock, 'Goldstickereien und Webereien in alter und neuer Zeit und das dazu verwandte Goldgespinst', Bayerisches Gewerbemuseum in Nürnberg, Nürnberg, 1884

4. M. Braun Ronsdorf, 'Gold and Silver Fabrics from Medieval to Modern Times', CIBA Review, 1961, 3.

5. For example:

E. Hoke,I. Petraschek-Heim, 'Microprobe Analysis of Gilded Silver Threads from Mediaeval Textiles', Studies in Conservation, 1977, 22;

L.P. Stodulski, D. Nauman, M. Kennedy, 'Techni- cal appendix, analysis of precious metal threads' in 'Fabrics in Celebration', from the Collection by P. Stolz Gilfoy, Catalog. Indianapolis Museum of Art, 1983;

M. Járó, 'The technological and analytical examination of metal threads on old textiles', Contributions of the 4th International Restorer Seminar, Veszprém, 1983 (Budapest, 1984)

6. E. Crowfoot, S. Chadwick-Hawkes, 'Early AngloSaxon Gold Braids', Medieval Archaeology, 1967, 11, p. 43

7. O. Doppelfeld, 'Das fränkische Frauengrab unter dem Chor des Kölner Domes', Germania, 1960 , 38, p. 94

8. M. Fleury, A. France-Lanord, op.cit. (see Ref. 2), p. 34

9. I. Petraschek-Heỉm, op.cit. (see Ref. 2), pp. 270 and 271

10. I. Petraschek-Heim, op.cit. (see Ref. 2), p.271

11. E. Hoke, 'Mikroanalytische Untersuchungen von Metallfäden aus Grab I in der Pfarrkirche Traismauer', 1977, Fundberichte aus Österreich, , 16, Wien, 1978, pp. 255-257

12. For example: O. v. Falke, op.cit. (see Ref. 1), E. Flemming, op.cit. (see Ref. 1), H. Schmidt, op.cit. (see Ref. 1), F. Bock, op.cit. (see Ref. 3)

13. F. Bock, op.cit. (see Ref. 3), p. 10

14. M. Járó, 'The Investigation of the Metal Embroidery Threads of the Hungarian Coronation Mantle by Scanning Electron Microscope and Physical Methods of Analysis', Preprints of the ICOM Committee for Conservation, 7th Triennial Meeting, Copenhagen, 1984, 1.24

15. Unpublished data. M. Balla, Technical University of Budapest, is kindly thanked for the neutron activation analysis

16. K.E. Nagy, 'An account of the preparation for the conservation of the Hungarian coronation mantle, Proceedings of the 4th International Restorer Seminar, Veszprém, 1983 (Budapest, 1984), p. 31

17. Theophilus Presbyter (12th century) describes this method, see Ref. 23, p. 127 
18. W.A. Oddy, 'Gold Wire in Antiquity', Aurum, 1981,5 , p. 8

19. A team in Hungary is currently attempting to reproduce the ancient manufacturing methods of metal threads. The results obtained up until now seem to prove this statement

20. M. Flury-Lemberg, 'Textile Conservation and Research', Schriften der Abegg Stiftung, Bern, 1988, p. 478 and p. 469

21. For example, F. Bock, op.cit. (see Ref.1) p. 27; M. Braun-Ronsdorf, op-cit. (see Ref. 4), p. 12; A. Geijer, op.cit. (see Ref. 1) p. 11

22. A.D. Barker, 'Gold Lace and Embroidery," Northern Society of Costume and Textiles Publication, 1980,1, p. $5-6$

23. Theophilus Presbyter, 'A kïlönféle muvességekrôl (Shedula Diversarum Artium)', translated from the medieval Latin with introduction and notes by Vilmos Takach, Muszaki Könyvkiado, Budapest, 1986, p. 127

24. 'Opus Anglicanum', Catalogue by Donald Kind, London, 1963, p. 13

25. M. Flury-Lemberg, op.cit. (see Ref. 20), p. 475

26. E. Hoke, I. Petraschek-Heim, Microprobe Analysis of Gilded Silver Threads from Mediaeval Textiles', Studies in Conservation, 1977, 22, pp. 49-62

27. J. Darah, Metal Threads and Filaments in: Recent Advances in the Conservation and Analysis of Artifacts, Institute of Archaeology', Jubilee Conference, Preprints, London, 1987, p. 214

28. N. Indictor, R.J. Koestler, C. Blair, A.E. Wardwell, "The Evaluation of Metal Wrappings from Medieval Textiles using Scanning Electron Microscopy - Energy Dispersive X-Ray Spectrometry', Textile History, 1988, 19 (1), pp. 3-22

29. Unpublished data. A. Toth, Institute of Technical Physics of the Hungarian Academy of Science, Budapest, is kindly thanked for the analysis

30. M. Járó, E. Gondar, 'Mediaeval Membrane 'Threads Used for Weaving and Embroidery', in Archaeometrical Research in Hungary', National Centre of Museums, Budapest, 1988, p. 256

31. N. Indictor et al., op. cit. (see Ref. 28), pp. 14-15

32. M. Járó Gondar, E., op. cit. (see Ref. 30), p. 259, p. 261 and unpublished data.

A. Toth, Research Institute of Technical Physics of the Hungarian Academy of Science is kindly thanked for the energy dispersive $\mathrm{X}$-ray analyses.

33. N. Indictor et al., op. cit. (see Ref. 28), p. 6

34. I. Petraschek-Heim, op. cit. (see Ref. 2), p. 269

35. M. Braun Ronsdorf, op. cit. (see Ref. 4), p. 6

36. A. Kolos, Museum of Arts and Crafts, Budapest, is kindly thanked for the photo.

37. Ms E. Gondar, INNOVATEXT Textile Engineering Institute, Budapest, is kindly thanked for the scanning electron-micrographs

38. Photo taken from M. Braun Ronsdorf, op. cit. (see Ref. 4) p. 3

39. Mr A. Toth, Research Institute of Technical Physics of the Hungarian Academy of Science, Budapest, is kindly thanked for the energy dispersive $\mathrm{X}$ ray analyses 